Клюсов О.М.

\title{
Пріоритетні вектори оптимізації надання медичної допомоги хворим з раком прямої кишки в умовах мегаполісу
}

Київський міський клінічний онкологічний центр, м. Київ, Україна

kmkoc.kiev@gmail.com

Клюсов А.Н.

Приоритетные векторы оптимизации оказания медицинской помощи больным с раком прямой кишки в условиях мегаполиса

Киевский городской клинический онкологический центр, г. Киев, Украина
Klusov O.M.

Priority vectors for optimizing medical care for patients with rectal cancer in the metropolis Kyiv city clinical oncology center, Kyiv, Ukraine

\section{ВетуII}

В час стрімкого розвитку інформаційних технологій, урбанізації, стрімкого розвитку наукових досліджень 3 фундаментальних проблем застосування генної, клітинної інженерії, тканинної терапії при різних нозологіях, питання медико-організаційного удосконалення надання медичної допомоги онкологічним хворим не втрачають актуальності. Сучасна світова статистика ВОО3 переконує, що саме онкологічна патологія, зростання смертності від якої зумовило ії друге рангове місце в структурі всіх причин смертності, має негативні прогнози до подальшого зростання ще на $45 \%$ до 2030 р. Зростання онкологічної захворюваності в першу чергу стосується категорії осіб 50 років і старше. Прогностичне зростання поширеності онкологічної патології пов'язують в тому числі із зростанням впливу екологічних проблем, урбанізації, поширенням саморуйнівних стереотипів та шкідливих звичок, «постарінням» населення, соціально-економічним збіднінням населення, комплексним погіршенням стану здоров'я населення [1-5].

Метою дослідження стало обгрунтування доцільності удосконалення організації надання медичної допомоги онкологічним хворим, його пріоритетних векторів в умовах українського мегаполісу (м. Київ) на прикладі локалізації раку в прямій кишці.

\section{Матеріали та методи}

Дослідження сплановано для виконання за послідовними організаційними етапами, де результати попереднього етапу ставали інформаційним підгрунтям для виконання наступних. Для початку була вивчена динаміка та регіональні статево-вікові особливості основних статистичних показників офіційної звітності за класом хвороб новоутворення 3 деталізацією за їх злоякісністю та локалізацією, організації надання медичної допомоги хворим 3 новоутвореннями, передбачало ретроспективний аналіз даних офіційної статистичної звітності за період 2011-2017 рр. (всього опрацьовано 1520 од. табличних матеріалів). Методично дослідження базувалося на системному підході, також використано методи структурного i логічного контент-аналізу, описово-аналітичного моделювання, організаційного експерименту, медико-статистичний метод, 3 допомогою якого на всіх етапах дослідження відбувався підрахунок статистичної достовірності, репрезентативності цифрового матеріалу.

\section{Результати дослідження та їх обговорення}

За результатами проведеного дослідження за період 2011-2017 pp. 3'ясовано, що серед киян продовжує зростати захворюваність на онкологічну патологію $(+3,96 \%, 3357,3$ до 371,46 на 100 тис. населення), продовжує зростати контингент хворих на рак $(+17,7 \%$, 3 2227,2 до 2622,5 на 100 тис. населення). Із зменшенням відсотку виявлення злоякісних новоутворень під час профілактичних оглядів (з 29,7\% до 28,0\%), зростає відсоток занедбаних випадів раку (з 14,7\% до 17,0\%). $\mathrm{He}$ дивлячись на те, що серед мешканців м. Києва відсоток виявлення злоякісних новоутворень під час профілактичних обстежень $\epsilon$ найвищим (58,3\%), виявлені тенденції зростання відсотку пізніх стадій захворювання серед всіх випадків встановлення вперше онкологічної патології, негативно позначається на працездатності, прогнозі для життя мешканців мегаполісу. Не дивлячись на те, що багато видів раку в світі вважаються виліковними, успішність медичного втручання залежить від його своєчасності, що обгрунтовує доцільність удосконалення організації надання медичної допомоги онкологічним хворим в умовах мегаполісу, зокрема із локалізацією злоякісного новоутворення в прямій кишці. 
Одним із векторів, який було впроваджено після концептуального обгрунтування доцільності його впровадження в м. Києві, стало посилення профілактичної складової надання медичної допомоги, що включало: широке громадське обговорення важливості збереження здоров'я та ефективності проходження своєчасних профілактичних обстежень на фоні повного здоров'я, а не лише при появі скарг та симптомів хвороби; залучення до широкого інформування населення на індивідуальному, груповому та популяційному рівні не лише медиків ПМД, а й ЗМІ, громадських організацій та об’єднань; стимули для медичної активності населення; посилення активності медичної та немедичної громадськості, медичних об'єднань.

Наступним вектором, пріоритетність посилення якого була доведена нами стало посилення кадрового потенціалу первинної медичної допомоги та онкологічної служби м. Києва. Для його реалізації планується: планування та проведення заходів із підняття престижу лікарської спеціальності, зростання поваги до медиків у суспільстві в цілому; запровадження мотивуючої системи оплати праці в залежності від обсягу та ефективності надання медичної допомоги; моніторинг з плануванням кадрового потенціалу онкологічної служби та лікарів первинної ланки; запровадження інформатизації робочих місць лікарів, телемедичних технологій, єдиного медичного простору; вдосконалення навичок та безперервне професійне навчання 3 передбаченими заняттями на робочому місці, тренінгами, семінарами, заняттями в симуляційних тренінгових класах по оволодінню необхідними 3 точки зору самого сімейного лікаря знаннями та практичними навичками щодо інновацій в практичній онкології.

За результатами вивчення взаємодії первинної та спеціалізованої медичної допомоги у наданні медичної допомоги пацієнтам 3 новоутвореннями нами обгрунтовано доцільність удосконалення вектору координації надання медичної допомоги таким хворим, який включав злагоджену взаємодію лікаря первинного контакту 3 родинами на дільниці та спеціалізованою, високоспеціалізованою онкологічною допомогою 3 дотриманням стратегій ВООЗ «Здоров'я для всіх» та «Здоров'я: 2020» щодо доступності, рівності, справедливості у отриманні медичної допомоги 3 пріоритетністю превентивного підходу; широке запровадження сучасних медико-організаційних та медико-профілактичних технологій; створення та підтримка єдиного медичного інформаційного простору; удосконалення моніторингу якості проведення первинної профілактики; створення реєстру осіб з факторами ризику розвитку раку прямої кишки; моніторинг дотримання стандартів та проколів надання медичної допомоги, запровадження державних протоколів та стандартів; запровадження медико-організаційної технології формування маршруту пацієнта з групи ризику розвитку раку прямої кишки; злагоджена координована взаємодія між закладами охорони здоров'я, які надають різні види медичної допомоги онкологічним хворим в мегаполісі, в тому числі приватної форми власності. Окремо розглядалася ідея запровадження технології прямих і зворотних інформаційних зв'язків між надавачами медичної допомоги онкологічним хворим, на прикладі раку прямої кишки, 3 вільним вибором провайдерів іiі надання в м. Києві.

Для можливості запровадження обгрунтованих інновацій набуває необхідності посилення вектору достатнього матеріально-технічного забезпечення надання медичної допомоги онкологічним хворим. Розвиток i посилення вектору включає планування витрат на дооснащення закладів первинної медичної допомоги згідно затвердженого МО3 табелю, витрат на обслуговування медичного обладнання, витратні матеріали, швидкі тести (зокрема для проведення аналізу калу на приховану кров). Реалізації означеного вектору сприяє фінансування програми «Здоров'я киян», в рамках якої можливим стає запровадження різних мотиваційних механізмів посилення профілактичної складової для всіх верств населення. Кращому впровадженню означеного вектора сприятимуть освітні програми 3 налагодження телекомунікації між медичними та профільними освітніми закладами, в тому числі для проведення телемедичних консультацій, комплексного виконання можливих грантових досліджень та програм. Щодо надання медичної допомоги, іï фінансової складової, необхідно враховувати індивідуальні потреби і фінансові можливості кожного пацієнта, забезпечивши його право здійснювати співоплату за проведене втручання, лікування з різних фінансових джерел.

Посилення вектору моніторингу впровадження запропонованих інновацій, ефективного керівництва ними включає інформаційно-методичне забезпечення 3 вивченням динаміки змін стану онкологічного здоров'я серед мешканців столиці за запропонованими індикаторами.

\section{Перспективи подальших досліджень}

Запровадження медико-організаційної технології розробки та корекції маршруту пацієнта при підозрі на рак прямої кишки, розробленої з урахуванням практичних настанов організації ранньої діагностики раку прямої кишки (WGO Всесвітньої гастроентерологічної організації та рекомендації UICC Міжнародного протиракового союзу), передбачає проведення опитування на виявлення факторів ризику, здійснення профілактичних діагностичних досліджень, в т.ч. швидкого тесту калу на приховану кров щорічно особам у віці 50-75 років, а особам 3 групи ризику два рази на рік, при позитивному результаті якого доцільним визначено направлення для продовження діагностики у онколога, проктолога (в умовах закладів охорони здоров'я, які надають спеціалізовану медичну допомогу). Також міжнародними дослідженнями ефективним визнано запровадження «дружнього підходу» у спілкуванні 3 пацієнтом, який передбачає детальну інформацію при запиті пацієнта на неї, особливо щодо порад змінити спосіб життя, харчування у подоланні керованих факторів ризику розвитку та прогресування раку прямої кишки. Різностороннє врахування індивідуальних особливостей 
пацієнта передбачає формування індивідуальної програми профілактичних діагностичних обстежень або індивідуальну програму лікування та реабілітації, до реалізації якої залучається також сімейний лікар, родина хворого на рак прямої кишки.

\section{Висновки}

Реалізація обгрунтованого посилення вищенаведених пріоритетних векторів удосконалення надання медичної допомоги хворим з раком прямої кишки в умовах мегаполісу забезпечила удосконалення інтегрованої організації надання медичної допомоги таким хворим в столиці. Започатковане таким чином функціонально-організаційне удосконалення дасть змогу наблизити надання профілактичних діагностичних i лікувальних послуг до населення мегаполісу, збільшити кількість звернень 3 профілактичною метою, що прогностично підвищить ефективність використання матеріально-технічних та кадрових ресурсів у задоволенні потреб населення у доступній, своєчасній, ефективній медичній допомозі.

Розвиток науково обгрунтованих пріоритетних векторів оптимізації надання медичної допомоги онкологічним хворим з раком прямої кишки. Забезпечення впровадження сучасних ефективних нововведень координації дозволить з урахуванням кращого світового досвіду та регіональних особливостей дасть змогу подальшого розвитку та реалізації обгрунтованої удосконаленої функціонально-організаційної моделі надання медичної допомоги онкологічним хворим з раком прямої кишки в умовах мегаполісу (на прикладі м. Києва), 3 урахуванням унікальних демографічних, соціальногігієнічних, соціально-економічних чинників, властивих українському мегаполісу, що мають вплив на формування здоров'я населення, яке проживає у ньому.

\section{Література}

1. World health statistics 2013 : ВООЗ (Документи Всесвітньої організації охорони здоров'я) / World Health Organization. - Geneva : WHO, 2013. - 168 p.

2. World health statistics 2014 : ВОО3 (Документи Всесвітньої організації охорони здоров'я) / World Health Organization. - Geneva : WHO, 2014. - 178 p.

3. Women live longer than men even during severe famines and epidemics / V. Zarulli, J. A. Barthold Jones, A. Oksuzyan [et al.] // Proc. Natl. Acad. Sci. USA. - 2018. - Vol. 115 (4). - P. E832-E840. doi: 10.1073/pnas.1701535115. Epub 2018 Jan 8.

4. WHO Health 2020. A European Policy Framework and Strategy for the 21st Century. - Copenhagen, 2013. - $190 \mathrm{p}$.

5. UNHCR global report 2008. Geneva: Office of the United Nations High Commissioner for Refugees: 2008 [Електронний ресурс]. - Режим доступу: http://www.unhcr.org/pages/49c3646c278.html. - Назва 3 екрана.

\section{References}

1. World health statistics 2013 / World Health Organization. - Geneva : WHO, 2013. - 168 p.

2. World health statistics 2014 / World Health Organization. - Geneva : WHO, 2014. - 178 p.

3. Women live longer than men even during severe famines and epidemics / V. Zarulli, J. A. Barthold Jones, A. Oksuzyan [et al.] // Proc. Natl. Acad. Sci. USA. 2018;Vol. 115 (4);E832-40. doi: 10.1073/pnas.1701535115. Epub 2018 Jan 8.

4. WHO Health 2020. A European Policy Framework and Strategy for the 21st Century. - Copenhagen, 2013. - $190 \mathrm{p}$.

5. UNHCR global report 2008. Geneva: Office of the United Nations High Commissioner for Refugees: 2008 [Electronnyj resurs]. - Rezhym dostupu: http://www.unhcr.org/pages/49c3646c278.html.

Дата надходження рукопису до редакції: 13.01 .2020 p.

Цілі наукового дослідження. Медико-соціальні аспекти онкологічної патології не втрачають актуальності в світлі зростання поширеності факторів ризику виникнення онкологічної патології, змін соціально-економічного благополуччя населення тощо.

Методологія та наукові підходи. Використані методи контент-аналізу, моделювання, організаційного експерименту та медико-статистичний. Динаміка та регіональні статево-вікові особливості новоутворень, організації надання медичної допомоги хворим з новоутвореннями, передбачало ретроспективний аналіз даних офіційної статистичної звітності за період 2011-2017 рр. (всього опрацьовано 1520 од. табличних матеріалів).

Результати. Наведено обгрунтовані та реалізовані пріоритетні вектори оптимізації надання медичної допомоги онкологічним хворим в умовах мегаполісу, зокрема з удосконалення профілактичної складової координації надання медичної допомоги, iї матеріально-технічного, кадрового забезпечення з моніторингом запропонованих інновацій при ефективному керівництві процесу їх впровадження.

Висновки. Забезпечення впровадження обгрунтованих векторів дасть змогу подальшого розвитку та реалізації обгрунтованої удосконаленої функціонально-організаційної моделі надання медичної допомоги онкологічним хворим з раком прямої кишки в умовах мегаполісу (на прикладі м. Києва), з урахуванням унікальних демографічних, соціально- 
гігієнічних, соціально-економічних чинників, властивих українському мегаполісу, що мають вплив на формування здоров'я населення, яке проживає у ньому.

Ключові слова: онкологічна допомога, рак прямої кишки, медико-організаційні чинники.

Цели научного исследования. Медико-социальные аспекты онкологической патологии не теряют актуальности в свете роста распространенности факторов риска возникновения онкологической патологии, изменений социальноэкономического благополучия населения т.д.

Методология и научные подходы. Использованные методы контент-анализа, моделирования, организационного эксперимента и медико-статистический. Динамика и региональные поло-возрастные особенности новообразований, организации оказания медицинской помощи больным с новообразованиями, предусматривало ретроспективный анализ данных официальной статистической отчетности за период 2011-2017 гг. (всего 1520 ед. табличных материалов).

Результаты. Приведены обоснованные и реализованные приоритетные векторы оптимизации оказания медицинской помощи онкологическим больным в условиях мегаполиса, в частности с усовершенствованием профилактической составляющей координации оказания медицинской помощи, ее материально-технического, кадрового обеспечения с мониторингом предложенных инноваций при эффективном руководстве процессом их внедрения.

Выводы. Обеспечение внедрения обоснованных векторов даст возможность дальнейшего развития и реализации обоснованной усовершенствованной функционально-организацинной модели оказания медицинской помощи онкологическим больным с раком прямой кишки в условиях мегаполиса (на примере г. Киева), с учетом уникальных демографических, социально-гигиенических, социально-экономических характеристик, свойственных украинскому мегаполису, которые влияют на формирование здоровья населения, проживающего в нем.

Ключевые слова: онкологическая помощь, рак прямой кишки, медико-организационные факторы.

Purposes of scientific research. Medical and social aspects of oncological pathology do not lose relevance in the light of the increase in the prevalence of risk factors of oncological pathology, changes in social and economic well-being of the population.

Methodology and scientific approaches. Used methods of content analysis, modeling, organizational experiment and medical and statistical. Dynamics and regional sex-and-age peculiarities of neoplasms, organization of medical care for patients with neoplasms, provided for retrospective analysis of official statistical reporting data for the period 2011-2017 (a total of 1,520 units tabular materials).

Results. Justified and implemented priority vectors of optimization of medical care for oncological patients in metropolis conditions are presented, in particular, with improvement of preventive component of coordination of medical care, its logistics, personnel support with monitoring of proposed innovations with effective management of their implementation process.

Conclusions. Ensuring the introduction of reasonable vectors will make it possible to further develop and implement a well-founded improved functional and organizational model of medical care for oncological patients with rectal cancer in the conditions of the metropolis (on the example of Kyiv), taking into account the unique demographic, social and hygienic, socioeconomic characteristics of the Ukrainian metropolis, which affect the formation of the health of the population living in it.

Key words: oncological care, rectal cancer, medical and organizational factors.

\section{Відомості про автора}

Клюсов Олександр Миколайович - директор Київського міського клінічного онкологічного центру, аспірант кафедри управління охороною здоров'я НМАПО імені П.Л. Шупика; вул. Дорогожицька, 9, Київ, 04112, Україна.

+380 (66) 273-17-73, kmkoc.kiev@gmail.com. 